\title{
Treatment of equine degenerative joint disease with autologous peripheral blood-derived mesenchymal stem cells: a case report
}

\author{
Een degeneratieve gewrichtsaandoening behandeld met autologe equine \\ mesenchymale stamcellen wit het perifeer bloed
}

\author{
${ }^{1}$ J. H. Spaas, ${ }^{2}$ M. Oosterlinck, ${ }^{3}$ S. Broeckx, ${ }^{2}$ M. Dumoulin, ${ }^{4}$ J. Saunders, ${ }^{3}$ A. Van Soom, ${ }^{2}$ F. Pille, \\ ${ }^{1}$ G. R. Van de Walle \\ ${ }^{1}$ Department of Comparative Physiology and Biometrics, ${ }^{2}$ Department of Surgery and Anesthesiology \\ of Domestic Animals, ${ }^{3}$ Department of Reproduction, Obstetrics and Herd Health, ${ }^{4}$ Department of \\ Veterinary Medical Imaging and Small Animal Orthopedics, Faculty of Veterinary Medicine, Ghent \\ University, B-9820 Merelbeke, Belgium
}

\author{
Jan.Spaas@ugent.be
}

\begin{abstract}
A 5-year-old German Warmblood stallion with chronic lameness, attributable to degenerative joint disease (DJD) of the pastern joint unresponsive to medical treatments, was treated with autologous mesenchymal stem cells (MSC). These MSC were isolated from the peripheral blood (PB) of the patient and injected into the pastern joint, at a concentration of $2.5 \times 10^{6}$ cells, twice with an 8 -week interval. The positive response to this stem cell treatment was documented by visual gait evaluation as well as objective pressure plate analyses. This paper is the first to describe the use of autologous PB-derived MSC to treat a horse suffering from chronic DJD. The favorable outcome of this single case may stimulate further research on the use of equine peripheral blood as a source of autologous MSC in equine regenerative medicine.
\end{abstract}

\section{SAMENVATTING}

Een vijfjarige Duitse warmbloedhengst die chronisch mank was ten gevolge van een degeneratieve aandoening in het kroongewricht en die geen verbetering vertoonde na conservatieve therapieën, werd behandeld met autologe mesenchymale stamcellen (MSC). Deze MSC werden geïsoleerd uit het perifeer bloed van de patiënt en 2,5 miljoen van deze cellen werden in het gewricht geïnjecteerd, tweemaal met een interval van acht weken. De positieve evolutie na behandeling werd gedocumenteerd aan de hand van een klinische evaluatie en objectieve drukplaatanalysen.

In dit artikel wordt voor de eerste maal het gebruik van perifeer bloed beschreven als bron van MSC voor het behandelen van een degeneratieve gewrichtsaandoening bij een paard.

\section{INTRODUCTION}

Degenerative joint disease is a major cause of diminished athletic function and wastage in performance horses (Frisbie 2005; Jeffcott et al. 1982; McIlwraith 1982). Ideally, all treatment should be based upon a good knowledge of the anatomy and physiology of the normal joints and the processes occurring during degeneration and repair (Goodrich and Nixon 2006; McIlwraith and Vachon 1988; Nizolek and White 1981). Initially, such treatment should include some degree of rest or exercise restriction. Medical treatments for DJD may include anti-inflammatory and analgesic drugs to reduce inflammation and pain, and so-called disease modifying drugs, such as glucosamine or chondroitin sulphate or hyaluronic acid (Goodrich and Nixon 2006; Malone 2002; Nizolek and White 1981). In the presence of severe cartilage and bone changes, the use of articular cartilage curettage, osteophyte removal and even arthrodesis could be suitable in some cases (Malone 2002; Zubrod and Schneider 2005). Nevertheless, the aforementioned therapies are me- rely palliative or may aim at an enhanced repair, albeit without actual regeneration of the affected joint. Over the last decades, the field of equine regenerative medicine has been getting increased attention and the use of stem cells to treat joint pathologies appears to be a promising strategy to regenerate injured tissues by differentiation towards cells with a hyaline-like cartilage morphology and which are able to produce cartilagespecific components, such as collagen type II and glycosaminoglycans (Berg et al. 2009; Koch and Betts 2007).

Stem cells are defined as cells displaying a self-renewal capacity either with or without differentiation, depending on the symmetry of the division (Donovan and Gearhart 2001). More specifically, MSC are adult stem cells derived from the mesodermal germ layer. Current clinical regenerative therapies with MSC in horses mainly use bone marrow (BM)-derived MSC for the treatment of tendinopathies (Crovace et al. 2007; Smith 2006, 2008; Smith et al. 2003; Violini et al. 2009) and BM- or adipose tissue (AT)-derived MSC for the treatment of osteoarthritis (Frisbie et al. 2009). 
In general, obtaining BM and AT samples is invasive and they are quite difficult to harvest. As an alternative, scientists have suggested umbilical cord blood (UCB), which, in humans, can be easily collected at birth. However, in horses, autologous UCB is not always available and a sterile collection is only possible under highly hygienic circumstances, which is difficult to achieve under field circumstances. The disadvantages of UCB can be avoided by using peripheral blood (PB) as a source for MSC. Since the collection of a sterile blood sample can easily be performed by any equine practitioner, $\mathrm{PB}$ is a readily accessible source of autologous MSC when injuries occur.

This paper is the first to describe the use of autologous PB-derived MSC to treat a horse suffering from chronic lameness attributable to DJD.

\section{CASE HISTORY}

One year before the injection of autologous PB-derived MSC, a 5-year-old German Warmblood stallion was presented with severe unilateral forelimb lameness, attributable to DJD of the pastern joint. The diagnosis was made based on clinical and radiographic examination and a positive response to intra-articular anesthesia. Dorsopalmar and lateromedial radiographs revealed periarticular new bone formation (Figure 1). Initial medical treatment with oral non-steroidal anti-inflammatory drugs and box rest during two months, and subsequently the intra-articular administration of steroidal anti-inflammatory medication and hyaluronic acid did not improve the impaired locomotion. Two months later, an additional period of one month of complete box rest and limited movement in a small paddock for the following five months did not show any improvement of the lameness. Given the lack of response to therapy after almost one year, the owners opted for treatment with autologous PB-derived MSC. The ethical committee of the Faculty of Veterinary Medicine, Ghent University, Belgium (EC2010-147) approved the experimental design.

\section{TREATMENT}

Ten $\mathrm{mL}$ of blood was taken from the vena jugularis of the patient and centrifuged at $1000 \mathrm{xg}$ for $20 \mathrm{~min}$ utes at room temperature (RT). The buffy coat fraction was collected and diluted 1:1 with phosphate buffered saline (PBS). Subsequently, the cell suspension was gently layered on a Percoll gradient (density 1.080 $\mathrm{g} / \mathrm{mL}$; GE Healthcare) and centrifuged at $600 \mathrm{xg}$ for 15 minutes at RT. The MSC were maintained and characterized by the presence or absence of different immunophenotypic markers and by in vitro differentiation towards osteoblasts, chondroblasts and adipocytes as previously described (De Schauwer et al. 2011).

For the first intra-articular injection, $2.5 \times 10^{6}$ autologous PB-derived MSC of passage $1\left(\mathrm{P}_{1}\right)$ were resuspended in $2.5 \mathrm{~mL}$ of sterile PBS with $50 \mu \mathrm{g} / \mathrm{mL}$ gentamicin (Sigma-Aldrich, Bornem, Antwerp, Belgium) and injected into the pastern joint of the patient. A si-
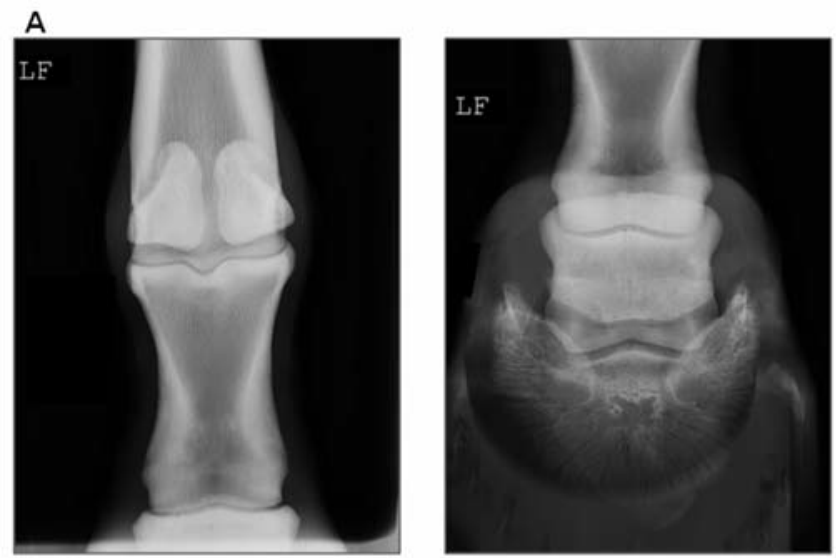

B
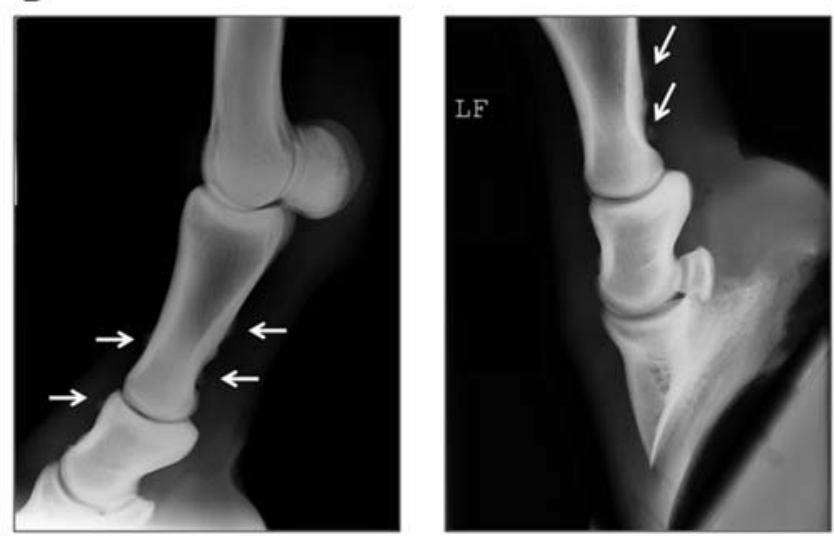

Figure 1. Dorsopalmar (A) and lateromedial (B) radiographic images of the pastern joint. The images on the left are weight-bearing and on the right using the podoblock. The white arrows indicate the periarticular new bone formation.

milar injection was repeated eight weeks later with cryopreserved MSC of P1, which were further cultured up to $\mathrm{P}_{3}$. The intra-articular injections were performed after the clipping and aseptic preparation of the skin, as is routinely done before an intra-articular treatment is started.

Figure 2 gives an overview of the timing of the injections with the autologous PB-derived MSC and all evaluations of the patient, as described below.

\section{OUTCOME}

\section{Clinical assessment}

Clinical evaluation was performed four weeks before injection $\left(T_{1}\right)$, and at 4-week-intervals after the first injection $\left(T_{1}=4\right.$ weeks, $T_{2}=8$ weeks, $T_{3}=12$ weeks and $\mathrm{T}_{4}=16$ weeks), according to the scoring system of the American Association of Equine Practitioners (AAEP) by the same team of veterinarians: grade 0 corresponds to soundness and grade 5 to non-weightbearing lameness. At every time point, flexion tests of the affected lower limb were performed and the results were graded from 0 (no response) to 3 (severe lameness).

Four weeks before the first injection $\left(\mathrm{T}_{-1}\right)$, the la- 


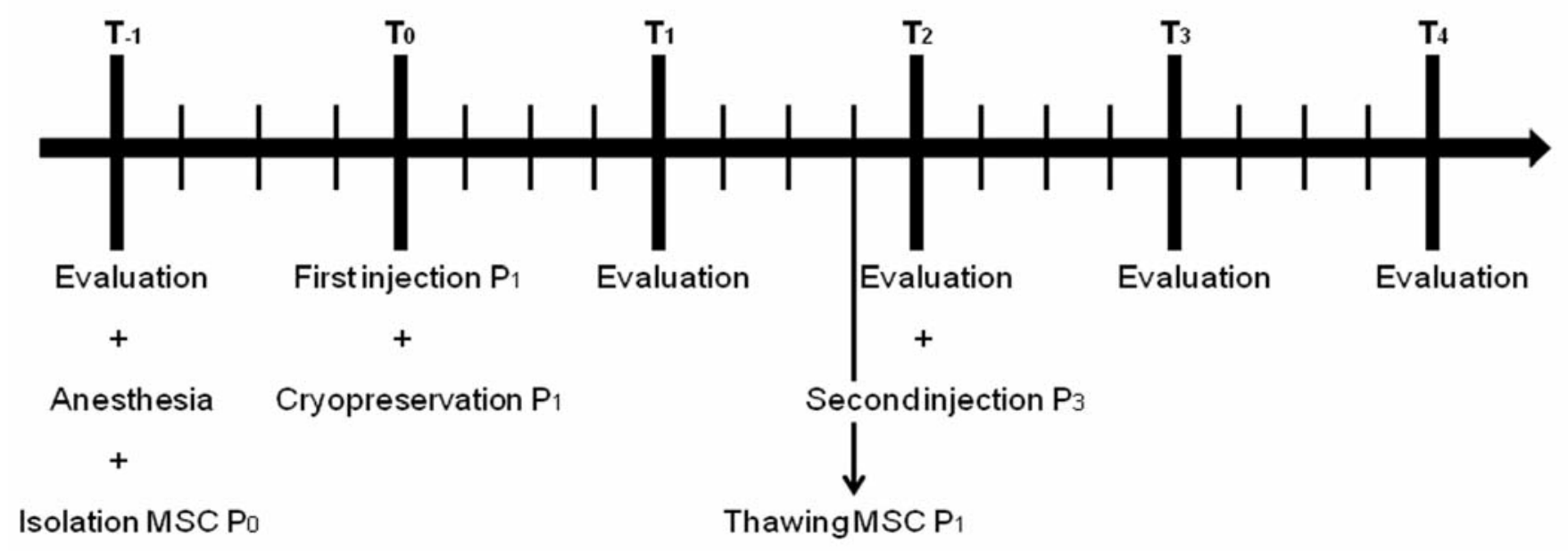

Figure 2. Timeline of equine mesenchymal stem cells (MSC) injections and evaluation intervals. A 5-year-old stallion with chronic lameness attributable to degenerative joint disease of the pastern joint was treated with autologous peripheral blood-derived MSC. Clinical evaluations and pressure plate analyses were performed 4 weeks before $\left(T_{-1}\right)$ and at 4-week-intervals ( $T_{1}=4$ weeks, $T_{2}=8$ weeks, $T_{3}=12$ weeks and $T_{4}=16$ weeks) after the first injection. $P=$ passage.

meness was evaluated and localized in the pastern joint using intra-articular anesthesia. A score of $4 / 5$ was given, which implied that the horse showed severe lameness at the walk and the trot in a straight line, with a marked head nod and shortened stride. Moreover, the flexion test of the distal limb was strongly positive $(3 / 3)$. Two days after the first injection with the autologous MSC, a mild diffuse swelling was observed at the pastern. This swelling disappeared within a day. After three days of box rest, gradual hand-walking was initiated. Four weeks after the first injection $\left(T_{1}\right)$, the lameness was obviously decreased, although it could still be observed consistently at the trot under all circumstances tested. Therefore, a score of $3 / 5$ was given. The flexion test at that time point was only slightly positive (1/3). After the second MSC injection, a mild, localized swelling together with a mild, transient lameness was observed at the walk. At all subsequent evaluation time points $\left(T_{2}, T_{3}\right.$ and $\left.T_{4}\right)$, only a residual irregularity at the trot could be noticed when lunging the horse (grade 2/5) and the flexion tests were negative $(0 / 3)$.

\section{Pressure plate analysis}

Recently, pressure plate analysis has been proposed as a useful tool to quantify equine locomotion and to evaluate the effects of a therapy in horses (Oosterlinck et al. 2010a; Oosterlinck et al. 2010b). Indeed, this technique allows simultaneous analyses of different limbs and provides detailed information on the loading of the different portions of the foot during a complete stance period. In this case, the horse was walked and trotted over a pressure plate (RSscan 3D 2m-system, RSscan International, Olen, Belgium) in a custommade walkway, as described previously (Oosterlinck et al. 2010a; Oosterlinck et al. 2010b). A trial was considered valid only if a complete hoof print of at least one forelimb was recorded while the velocity was within a preset range. Each measuring session was limited to the number of trials necessary to obtain five valid measurements of both forelimbs. The following kinetic variables were calculated for both forelimbs at the walk and at the trot, and expressed as \% symmetry (left/right $\mathrm{x}$ $100 \%$ ): (1) peak vertical force (PVF), i.e. the maximal vertical force value throughout the stance phase; (2) vertical impulse (VI), calculated by time integration of the force-time curves and (3) load rate (LR) of the vertical force curve.

The peak vertical force (PVF), vertical impulse (VI) and load rate (LR) symmetry ratios at all time points are presented in Figure 3. Already after the first injection with the autologous $\mathrm{PB}$-derived $\mathrm{MSC}$, an increase of the LR symmetry ratio was observed in both the walk and the trot, which even further increased considerably after the second injection (Figure 3). Clear improvements were also seen in the PVF and VI symmetry ratios, although these effects were more pronounced at the trot than at the walk (Figure 3).

\section{Medical imaging}

Routine dorsopalmar and lateromedial radiographic evaluation of the pastern joint did not reveal considerable changes after the autologous MSC therapy compared to pre-treatment radiographs (data not shown). Four weeks before stem cell therapy, an ultrasonographic examination was performed and did not show any abnormalities. Therefore, no further ultrasonography was performed.

\section{DISCUSSION}

Mesenchymal stem cells represent a very promising therapeutic tool for certain types of degenerative or traumatic diseases in different animal species, because 

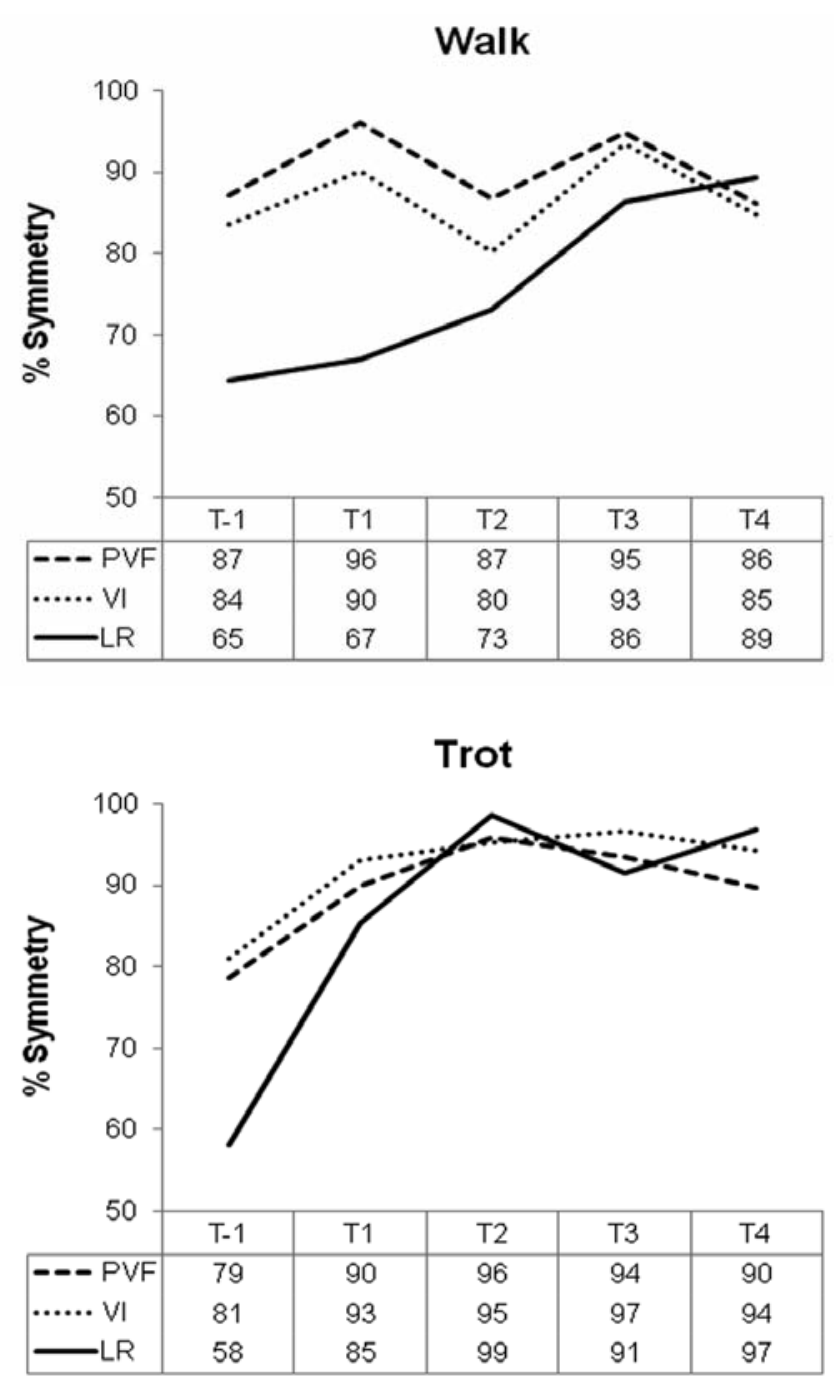

Figure 3. Pressure plate analyses at the walk and the trot. The patient was evaluated 4 weeks before $\left(T_{-1}\right)$ and at 4week-intervals $\left(T_{1}=4\right.$ weeks, $T_{2}=8$ weeks, $T_{3}=12$ weeks and $T_{4}=16$ weeks) after the first injection with autologous peripheral blood-derived mesenchymal stem cells (MSC) . The following parameters were measured: peak vertical force (PVF), vertical impulse (VI) and load rate (LR).

of their enormous plasticity and differentiation capacities. The in vivo use of MSC in equine veterinary medicine has been studied intensively, with several independent studies reporting regenerative effects, mainly in tendon and ligament injuries (Crovace et al. 2007; Smith 2008). Equine degenerative joint disease is one of the most common causes of early retirement and reformation of sport horses, and therefore, the use of MSC is currently being explored for its regenerative potential in this musculoskeletal injury (Berg et al. 2009; Koch and Betts 2007). To the knowledge of the authors, there are only reports on the in vivo use of equine adipose tissue (AT)-derived and bone marrow (BM)-derived MSC for the treatment of osteoarthritis (Frisbie et al. 2009; Wilke et al. 2007). In these studies, osteoarthritis was experimentally induced and the MSC were injected in the acute phase of the lesion (within 14 days). A short-term clinical improvement was noti- ced after MSC therapy, although this was not the case for the long-term follow-up of the horses. In contrast, a more recent study by McIlwraith showed no evidence of any clinically significant improvement in the joints injected with BM-MSC, but arthroscopic evaluation confirmed a significant increase in aggrecan production, repair tissue firmness and a trend for better overall repair tissue quality in BM-MSC-treated joints. (McIlwraith et al. 2011). This latter study emphasizes the importance of combining clinical evaluation with more scientifically-based parameters to evaluate the efficacy of MSC treatment in horses.

In the present case report, the authors describe for the first time the use of peripheral blood (PB)-derived MSC to treat a horse suffering from chronic lameness attributable to DJD of the pastern joint. A positive response to the therapy could already be demonstrated four weeks after the first injection, as assessed by the clinical evaluations and pressure plate analyses. For the latter, it was proven that the load rate (LR) symmetry ratio increased considerably in both gaits, indicating an increased speed of loading at the walk as well as at the trot. Moreover, a clear improvement in peak vertical force (PVF) and vertical impulse (VI) symmetry ratios was evident at the trot, indicating an increased symmetry of the weight-bearing function of the forelimbs. The lack of an overall increasing improvement in PVF and VI symmetry ratios at the walk is most likely associated with a lower reproducibility of the pressure plate analysis at the walk than at the trot, as previously reported (Oosterlinck et al. 2010a). Currently, i.e. one year after the MSC treatment, the stallion is not showing any signs of recurrent lameness and he is competing again (personal communication with the horse owner). Still, in order to truly confirm the effectiveness of PB-MSC, a double blinded standardized model should have been used with exactly the same induced lesions in a large number of horses, including control groups. Moreover, and in analogy to previously performed experiments in horses where the fate of injected BM-MSC was studied in an equine tendon injury model (Guest et al. 2010), fluorescently-labelled PB-MSC could be used to prove whether the in vivo cartilage regeneration is attributable to the MSC itself or rather to the products they secrete.

In conclusion, this case report is the first to describe the successful treatment of a patient suffering from chronic lameness attributable to DJD using autologous PB-derived MSC. It is clear that this single case study does not allow to draw definite conclusions on the clinical efficacy of the treatment protocol, nor does it allow for an extrapolation to other equine pathologies beyond DJD. However, the results of this case report are encouraging to further evaluate the efficacy of autologous PB-derived MSC in equine regenerative medicine.

\section{ACKNOWLEDGEMENTS}

This study was supported by a grant to the first author from the agency for Innovation by Science and Technology (IWT). 


\section{REFERENCES}

Berg, L., Koch, T., Heerkens, T., Bessonov, K., Thomsen, P. and Betts, D. (2009). Chondrogenic potential of mesenchymal stromal cells derived from equine bone marrow and umbilical cord blood. Veterinary and Comparative Orthopaedics and Traumatology : V.C.O.T 22, 363-370.

Crovace, A., Lacitignola, L., De Siena, R., Rossi, G. and Francioso, E. (2007). Cell therapy for tendon repair in horses: an experimental study. Veterinary Research Communications 31 Suppl 1, 281-283.

De Schauwer, C., Meyer, E., Cornillie, P., De Vliegher, S., Van de Walle, G.R., Hoogewijs, M., Declercq, H., Govaere, J., Demeyere, K., Cornelissen, M. and Van Soom, A. (2011). Optimization of the isolation, culture and characterization of equine umbilical cord blood mesenchymal stromal cells. Tissue Engineering Part C, Methods 17(11), 1061-1070.

Donovan, P.J. and Gearhart, J. (2001). The end of the beginning for pluripotent stem cells. Nature 414, 92-97.

Frisbie, D.D. (2005). Future directions in treatment of joint disease in horses. Veterinary Clinics of North America: Equine Practice 21, 713-724, viii.

Frisbie, D.D., Kisiday, J.D., Kawcak, C.E., Werpy, N.M. and McIlwraith, C.W. (2009). Evaluation of adipose-derived stromal vascular fraction or bone marrow-derived mesenchymal stem cells for treatment of osteoarthritis. Journal of Orthopaedic Research 27, 1675-1680.

Goodrich, L.R. and Nixon, A.J. (2006). Medical treatment of osteoarthritis in the horse - a review. The Veterinary Journal 171, 51-69.

Guest, D.J., Smith, M.R. and Allen, W.R. (2010). Equine embryonic stem-like cells and mesenchymal stromal cells have different survival rates and migration patterns following their injection into damaged superficial digital flexor tendon. Equine Veterinary Journal 42, 636-642.

Jeffcott, L.B., Rossdale, P.D., Freestone, J., Frank, C.J. and Towers-Clark, P.F. (1982). An assessment of wastage in thoroughbred racing from conception to 4 years of age. Equine Veterinary Journal 14, 185-198.

Koch, T.G. and Betts, D.H. (2007). Stem cell therapy for joint problems using the horse as a clinically relevant animal model. Expert opinion on biological therapy 7, 1621-1626.

Malone, E.D. (2002). Managing chronic arthritis. Veterinary Clinics of North America: Equine Practice 18, 411-437.

McIlwraith, C.W. (1982). Current concepts in equine degenerative joint disease. Journal of the American Veterinary Medical Association 180, 239-250.

McIlwraith, C.W., Frisbie, D.D., Rodkey, W.G., Kisiday, J.D., Werpy, N.M., Kawcak, C.E. and Steadman, J.R. (2011). Evaluation of intra-articular mesenchymal stem cells to augment healing of microfractured chondral defects. Arthroscopy 27, 1552-1561.

McIlwraith, C.W. and Vachon, A. (1988). Review of pathogenesis and treatment of degenerative joint disease. Equine Veterinary Journal. Supplement, 3-11.

Nizolek, D.J. and White, K.K. (1981). Corticosteroid and hyaluronic acid treatments in equine degenerative joint disease. A review. The Cornell veterinarian 71, 355-375.

Oosterlinck, M., Pille, F., Back, W., Dewulf, J. and Gasthuys, F. (2010a). Use of a stand-alone pressure plate for the objective evaluation of forelimb symmetry in sound ponies at walk and trot. The Veterinary Journal 183, 305-309.

Oosterlinck, M., Pille, F., Huppes, T., Gasthuys, F. and Back, W. (2010b). Comparison of pressure plate and force plate gait kinetics in sound Warmbloods at walk and trot. The Veterinary Journal 186, 347-351.
Smith, R.K. (2006). Stem cell technology in equine tendon and ligament injuries. The Veterinary Record 158, 140.

Smith, R.K. (2008). Mesenchymal stem cell therapy for equine tendinopathy. Disability and Rehabilitation 30, 1752-1758.

Smith, R.K., Korda, M., Blunn, G.W. and Goodship, A.E. (2003). Isolation and implantation of autologous equine mesenchymal stem cells from bone marrow into the superficial digital flexor tendon as a potential novel treatment. Equine Veterinary Journal 35, 99-102.

Violini, S., Ramelli, P., Pisani, L.F., Gorni, C. and Mariani, P. (2009). Horse bone marrow mesenchymal stem cells express embryo stem cell markers and show the ability for tenogenic differentiation by in vitro exposure to BMP-12. BMC Cell Biology 10, 29.

Wilke, M.M., Nydam, D.V. and Nixon, A.J. (2007). Enhanced early chondrogenesis in articular defects following arthroscopic mesenchymal stem cell implantation in an equine model. Journal of Orthopaedic Research 25, 913-925.

Zubrod, C.J. and Schneider, R.K. (2005). Arthrodesis techniques in horses. Veterinary Clinics of North America: Equine Practice 21, 691-711, vii. 
Dopharma B.V. is een dynamisch bedrijf dat op basis van eigen kennisbronnen veterinaire farmaceutische producten registreert en produceert. Zowel in het binnen- als buitenland biedt Dopharma een uitgebalanceerd pakket diergeneesmiddelen aan. Dopharma produceert 95\% van haar diergeneesmiddelen zelf, op eigen moderne GMP gecertificeerde productielijnen, waaronder een steriele plant. Voor een snelle distributie in Nederland heeft Dopharma een eigen expeditie afdeling. Binnen Dopharma Research B.V. worden registratiestudies verricht Hiertoe beschikt Dopharma Research over 2 laboratoria en een proefstal, waar de onderzoeken worden uitgevoerd in overeenstemming met de GLP principes.

WEGENS UITBREIDING VAN ONS MULTIDISCIPLINAIRE TEAM, ZIJN WIJ OP ZOEK NAAR EEN:

\section{MEDEWERKER TECHNISCHE ONDERSTEUNING (DIERENARTS M/V) O.B.V. EEN FULLTIME DIENSTVERBAND}

\section{FUNCTIE}

Technische ondersteuning van ons volledige productengamma, waaronder wij verstaan:

- Het vertalen van technische en wetenschappelijke informatie naar praktijkgerichte en/of

commerciële teksten ten behoeve van onze verkoop- en marketingmedewerkers in binnen en buitenland

- Informatievoorziening aan klanten en distributeurs, alsmede het oplossen van praktische vraagstukken

- Het houden van presentaties voor collega's, dierenartsen en veehouders

- Het volgen van de ontwikkelingen in de veehouderij op Europees niveau en interne communicatie en informatievoorziening hieromtrent

\section{PROFIEL}

- Dierenarts met enkele jaren praktijkervaring in de varkenshouderij

- Goede beheersing van MS Office (Word, Power Point en Excel)

- Uitstekende beheersing van Nederlandse en Engelse taal in woord en geschrift

- Een enthousiaste teamplayer met goede sociale en communicatieve vaardigheden

- Creativiteit en analytisch denkvermogen om verworven inzichten te vertalen naar de dagelijkse praktijk

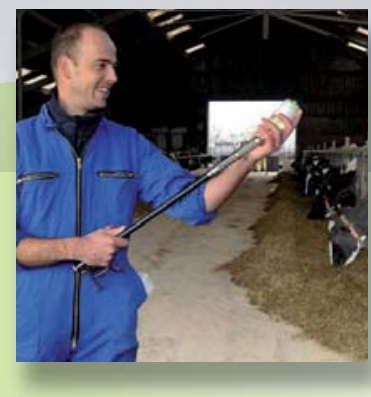

\section{WIJ BIEDEN}

- Een uitdagende en veelzijdige functie

- Een inspirerende werkomgeving

- Goede primaire en secundaire arbeidsvoorzieningen

\section{INFORMATIE}

Voor meer informatie over de functie kunt u contact opnemen met Ellis Draaijer, Technical support manager van Dopharma Research B.V., telefoonnummer + 31 (0) 16258 2000. Voor uitgebreide informatie over onze organisatie verwijzen wij u naar onze website www.dopharma.com

Mocht u belangstelling hebben voor deze vacature en herkent u zich in bovengenoemd profiel, dan zien wij uw sollicitatie t.a.v.Vivian Couwenberg, afdeling Personeelszaken (e-mail: pz@dopharma.com), graag binnen 4 weken na publicatiedatum tegemoet op onderstaand adres:

DOPHARMA VETERINAIRE FARMACA B.V.

POSTBUS 205

4940 AE RAAMSDONKSVEER

NEDERLAND

TEL. +31 (0)162 582000

E-MAIL: PR@DOPHARMA.COM 